\title{
Shabby and Shambling: Decadent Housing in Greys Avenue
}

Julia Gatley, School of Architecture \& Planning, University of Auckland, Auckland

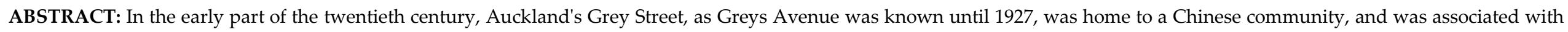

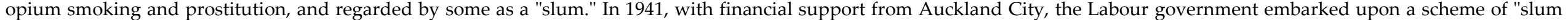

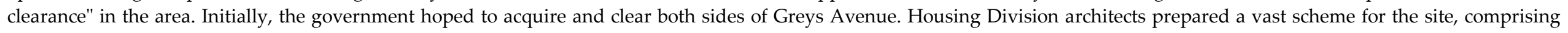

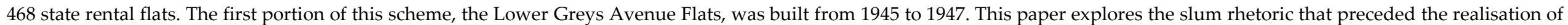

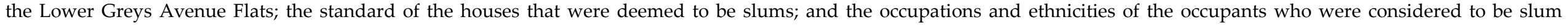

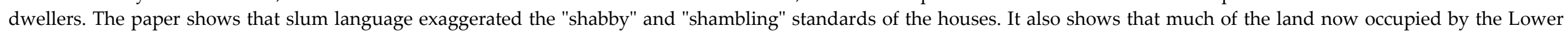

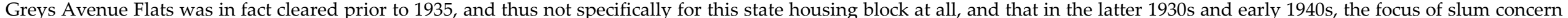
was further up the street, with houses that would not be cleared and replaced until the 1950s, '60s and '70s.

In 1940, Ernest Davis, the mayor of Auckland, wrote in a confidential report to his city councillors, that:

Grey [sic] Avenue is one of the City's outstanding eyesores. It should be eradicated without delay. Initiative on its restoration would be at least a beginning in slum-clearance measures which I am confident ratepayers will wholeheartedly approve. A start has to be made somewhere. Grey [sic] Avenue is that starting point. $^{1}$

The following year, the Labour Government, with a $£ 25,000$ contribution from Auckland City, embarked upon the rehabilitation of the area. The council and the government hoped that both sides of Greys Avenue would be acquired, cleared and rebuilt with public housing. Housing Division architects

${ }^{1}$ Davis "Decadent Areas" prepared a vast scheme for the site, comprising 468 state rental flats. Construction was delayed because of the Second World War. From 1945 to 1947, four blocks (50 units) were completed to this original design. These are the Lower Greys Avenue Flats. Construction to the south was delayed because post-war construction costs were disproportionately high. By the 1950s when the decision was made to proceed, the 1940s design was no longer considered appropriate and the Upper Greys Avenue Flats were redesigned to reflect technological developments. They were completed in 1958.

This paper explores the Greys Avenue buildings that were interpreted as slums, prior to their clearance to make way for the Greys Avenue Flats. It does so with reference to Alan Mayne's ideas about slum rhetoric and the deployment of slum language by middleclass commentators to mobilise support for slum clearance. It examines: the commitment by both central and local government to acquire and clear parts of Greys Avenue for public housing; the standard of the houses that were deemed to be slums; and the occupations and ethnicities of the occupants who were considered to be slum dwellers. To what extent, it asks, was the language an accurate reflection of the conditions?

In asking questions of the conditions in Greys Avenue, the paper revisits, teases out and complicates one of the arguments put forward in my 1997 Masters thesis on state flats of the latter 1930s and the 1940s. ${ }^{2}$ It differs further from my earlier work on Greys Avenue in the

\footnotetext{
2 Gatley "Labour Takes Command"
} 
more extensive use that it makes of Auckland City Council records.

The research findings surprised me. Given Greys Avenue's reputation for Chinese occupancy, opium-smoking and prostitution, I expected to find repeated references to Auckland's Chinese community in the early 1940s documents, and assumptions about the behaviours and activities of the Chinese residents, but instead the research shows that: (i) much of the land now occupied by the Lower Greys Avenue Flats was cleared prior to 1935 and only two remaining lots had to be cleared in 1945 to make way for this state housing scheme; and (ii) in the latter 1930s and early 1940s, the focus of slum concern was further up the street, where the Upper Greys Avenue block was built in the mid-tolate 1950s, and on the other side of the street, the east side, which was redeveloped more haphazardly in the 1960s and 1970s.

The Lower Greys Avenue Flats are a wellknown state rental housing scheme. The government acquired the site on 5 August
$1941,^{3}$ and was then responsible for the design and construction of the reinforced concrete flats that were built from 1945 and completed in 1947. Newspaper and journal articles reported it as Auckland's "First Step in Slum Clearance": "The 50-flat project now completed at Grey's Avenue is the first part of the slum clearance scheme decided upon by the Government in May, 1941."4 The New Zealand Herald elaborated:

With these three lots completed the first and most difficult part of the Government's slum clearance scheme in Auckland will be brought to a stage where it will transform a blighted area into a modern and dignified residential district making Grey's Avenue one of the finest streets in the city. ${ }^{5}$

Ten years before a start was made on the Greys Avenue Flats, New Zealand's housing surveys had drawn much attention to housing conditions. The 1935 housing surveys, which were required by central government and undertaken by local authorities, assessed housing standards nationwide. Houses were judged for structural strength and

\section{${ }^{3}$ CT 478/190, Auckland.}

4 "Auckland Achievement: Block of 50 State Flats as First Step in Slum Clearance" p 7.

5 "State Flats in City: Symonds Street and Grey's Avenue" p 6. overcrowding. Overcrowding was defined in terms of the number of people resident in a house compared with the number of bedrooms. Boys and girls over the age of ten were expected to sleep in separate bedrooms. In Auckland, it was reported that:

Much of the overcrowding revealed arose from the use of rooms where cooking was done in sleeping quarters, another factor being the use of unauthorised attic and basement rooms. A considerable amount of single-room occupancy was found chiefly in unauthorised apartments.

Of the total dwelling units 3337, or 23 per cent., were classified as only partially satisfactory in regard to equipment, conveniences and facilities of various kinds. A total of 3546 , or $24 \frac{1}{2}$ per cent., were definitely unsatisfactory. Unauthorised apartment, lodging and boarding houses were again the chief offenders. ${ }^{6}$

By the mid-1930s, the council had identified Greys Avenue and Airedale Street, which mirrored Greys Avenue on the east side of Queen Street, as the most urgent of Auckland's slums. Its aim for Greys Avenue was to remove 37 houses, three factories and one shop and to replace the cleared buildings with four-storeyed apartment buildings, comprising 125 flats. ${ }^{7}$ Thus the Auckland City

\footnotetext{
${ }^{6}$ Dock St Mission and Old Folk's Fellowship p 1.
}

7 "City Schemes; Housing and Works" 
Council's desire to acquire, clear and replace old buildings in Greys Avenue with apartments pre-dates central government's involvement by several years. Amid correspondence on the slum clearance proposal, Council files contain copies of the RIBA competition rules, ${ }^{8}$ suggesting that a competition for the design of the proposed apartment buildings was considered.

The new Labour government embarked on its state housing programme in 1936. It was soon apparent that the central government programme would not be limited to suburban developments, but would also include innercity state rental housing, in Auckland and Wellington at least. Upon learning of the government's interest in inner-city areas, the Auckland City Council invited it to consider the Greys Avenue area for slum clearance and replacement with state housing. The government accepted the council's recommendation and as a result the council's own, earlier, proposals for the site were not realised. ${ }^{9}$

\footnotetext{
${ }^{8}$ Auckland City Archives Box 91, File 34/226 Part 1.

9 "Housing Plans: the City Scheme" New Zealand Herald (Tuesday 3 November 1936). ACC Box 91, File 34/226
} Part 1.
The word "slum" runs throughout both official records and newspaper articles on the street that decade and the next. In 1940, CF Bennett, the real estate agent used by Auckland City for obtaining property valuations, commented that:

In Auckland City it is authoritatively stated that within a one and a half mile radius of our Town Hall there are over 700 houses designated as unfit for human habitation....

It cannot be denied that the blight of slumdom in our midst provides the breeding grounds not only for discontent crime and immorality but also for disease of every description. ${ }^{10}$

The descriptions often contained assumptions about ethnic minorities:

Aucklanders, young and old, are living in filthy, insanitary surroundings in the heart of the city. In old disused shops, ramshackle apartment houses and small slummy dwellings people are carrying on. These hovels are scarcely fit to house animals...

And what a block it is! It provides shelter, not only for shops, but for Hindus, Maoris, old-age pensioners, girls and youths who are there by night but out by day, and

${ }^{10}$ C.F.B. "Some thoughts on Planning for New Zealand's contribution to the New World Order," Note: Bennett's underlining. aged women. ${ }^{11}$

The description of Greys Avenue as a slum is repeated in later historical accounts such as Graham Bush's history of the Auckland City Council, where he described Greys Avenue as "pungent,"12 and my own Masters thesis, in which I accepted the term slum at face value. It is a word that needs to be questioned.

Australian historian Alan Mayne has shown that slums are myths: "They are constructions of the imagination."13 Upper and middle-class commentators associated slums with disorder, poverty, vice, criminality, drunkenness, immorality, promiscuity and disease. The term was encoded with the meanings of the dominant bourgeoisie, who took their own values and standards as benchmarks and judged the working classes against them, exacerbating the gulf between city and slum and thus between citizen and slum dweller. ${ }^{14}$ Use of the term obscured and distorted the spatial and social conditions of the places to

11 Sayers "Rat-Infested Slums Endanger Health of Aucklanders"

${ }^{12}$ Bush Decently and In Order: The Government of the City of Auckland 1840-1971 p 289.

${ }_{13}$ Mayne The Imagined Slum $\mathrm{p} 1$.

${ }^{14}$ Mayne The Imagined Slum pp 106-107. 
which it was applied. Indeed, reformers constructed the slum as "an agent of mobilization."15 Mayne writes:

All slumland depictions were mediated by the cultural milieux within which they were framed, and upon which their creators depended for comprehension and credibility. The slum was employed by both reformers and entertainers as a potent trigger device which mobilized bourgeois interest because it dovetailed with basic axioms of prevailing common-sense opinion about the good and the bad in contemporary society. ${ }^{16}$

Lynette Shum's work on Wellington's Haining Street, home to that city's Chinatown, provides a precedent for questioning the conditions in Greys Avenue. She examines assumptions about the stereotypical association between Chinese people and opium-smoking and prostitution, demonstrating that there are few records of arrests or convictions for opium or sex trade in Haining Street, and that there were few Chinese women in New Zealand other than wives or daughters of residents, meaning that if there was prostitution in Haining Street, the women were unlikely to have been Chinese. ${ }^{17}$ Shum also recognised the sensationalism

${ }^{15}$ Mayne The Imagined Slum $\mathrm{p} 137$.

${ }^{16}$ Mayne The Imagined Slum $\mathrm{p} 3$.

17 Shum "Remembering Chinatown" p 8. printed in the pages of local newspapers, which often bore little or no resemblance to the reality of the situation. ${ }^{18}$

Similarly, historian Ben Schrader has shown how town planning advocate Charles Reade, who lectured on town planning in Australia and New Zealand in 1914 and 1915, used slums as "agents of mobilization,"19 "exposing," and even exaggerating, the existence of overcrowding, "horrible conditions," miscegeny, and prostitution to trigger support for the introduction of more extensive town planning. ${ }^{20}$

In Auckland, Reade's tour coincided with the clearance of the Grey Street Gully to make way for Myers Park. The Myers Park project is relevant here because the lots on the east side of Grey Street (which was renamed Greys Avenue in 1927 ${ }^{21}$ backed on to the park and thus the park project demonstrates that the area had been of concern to the Auckland City

${ }^{18}$ Shum "Remembering Chinatown" p 79.

${ }^{19}$ Phrase quoted from Mayne The Imagined Slum p 137.

${ }^{20}$ Schrader "Avoiding the Mistakes of the "Mother

Country"'" pp 398-399.

${ }^{21}$ In a half-hearted attempt to change the character of the street, the Auckland City Council had changed the name from Grey Street to Greys Avenue in 1927. Bush Decently and In Order p 265.
Council for many years. The park project was conceptualised by CJ Parr, then mayor of Auckland, in 1913, ${ }^{22}$ and at Parr's invitation was funded by brewer, benefactor and former mayor of Auckland, Arthur Myers, and his wife Vera. The park required eight acres of land to be acquired from 25 different owners and cleared of 14 houses and other outbuildings. Parr repeatedly referred to the gully as a slum, describing it as a "veritable eyesore,"23 and commenting that it had "degenerated into a squalid and miserable quarter ... for many years an unhealthy and noisome neighbourhood, filled with ancient and slumlike buildings." 24

The extent to which the area was in fact a slum is difficult to gauge. The houses may have been "old and dilapidated," 25 and the vegetation overgrown and unkempt, but with only 14 houses in its eight acres the gully was never congested, and rather than calling it a slum, a Herald editorial suggested that it "would have probably become "slum'" had it not been cleared and converted into a park. ${ }^{26}$

22 "New Park" p 8

23 "New Park" p 8.

${ }^{24}$ Parr "Parks, Playgrounds, and Open Spaces" p 238.

25 "New Park" p 8.

26 "The Myers Park" p 6. 
Others would later recall that the condemned Grey Street Gully cottages were "largely occupied by Chinese." 27 Street directories do not confirm this, but rather suggest that most of the occupants, who were predominantly tenants not owners, were labourers or pensioners of British/European descent. ${ }^{28}$ However, in her writing on Haining Street, Shum suggested that Wellington's "otherwise comprehensive" street directories barely mention the Chinese people who were resident in particular streets. ${ }^{29}$ If this was the case in Wellington, then it may have been the

27 "Former Mayoress" p 123.

${ }^{28}$ The six houses on Adams Lane were occupied by Sarah Black, widow; John Gill Cain, cook, and his wife Sarah Ann Cain; Margaret Downing, spinster; Frederick Gardiner, labourer; Charles Patrick Hing, blacksmith, and his wife Margaret Hing; and Frank Taylor, labourer. The 5 houses on Lancelot Terrace were occupied by Mrs Duncan, occupation not known; Sydney Goodman, driver, and his wife Louisa Goodman; John Haslett, expressman, and his wife May Haslett; Alexander Stephen Mutch, labourer, and his wife; and Thomas Wilkinson, labourer, and his wife. The remaining 3 houses on Queen Street and Scotia Place were occupied by Mary Cooper, pensioner and widow; William Pearce, painter, and his wife Mildred Elizabeth Pearce; and

Thomas Jowsey, retired farmer, and his wife Caroline Jowsey. See Town Clerk"s Series 275 Box 5 File 1913/304, Auckland City Archives, Auckland; Cleave"s Post Office Directories; and NZ Electoral Rolls.

${ }^{29}$ Shum "Remembering Chinatown" pp 75,92. case in Auckland too and thus the absence of Chinese names from the street directories does not necessarily mean their absence from these cottages.

Prior to the opening of Myers Park in 1915, the streets circuiting the Grey Street Gully were home to a mixture of welfare organizations, churches, hotels, housing, a crèche and various businesses. Following its opening, Arthur Myers and his wife Vera funded the Myers Kindergarten and School for Backward Children and the associated children's playground in the park. The facilities for children were opened in November 1916. Other organisations with a specific interest in children, youths and women then initiated new buildings in the vicinity, including a Young Women's Christian Association (YWCA) headquarters (1918) and hostel (1928) in Scotia Place and a Salvation Army congress hall (1928) in Greys Avenue. These new facilities capitalised on the park amenities. ${ }^{30}$ Further, the park, kindergarten and playground projects shared moralist, nationalist, militarist and hygienist agendas, all of which were reinforced by the

${ }^{30}$ Cusins-Lewer \& Gatley "The "Myers Park Experiment" (1913-1916) and Its Legacy in Auckland" pp 59-80. later facilities. ${ }^{31}$

Concurrently, the lower (northern) end of Greys Avenue, which formerly intersected with Cook Street, emerged as Auckland's Chinatown. Chinese New Zealander Eva Wong $\mathrm{Ng}$ describes its development thus:

Wah Lee's store was one of the earliest Chinese operated shops in Grey Street. About 1904, it began selling Chinese food stuff in premises next to the Market Hotel. As well as retailing, Wah Lee's acted as a bank for the Chinese, a depot for letters arriving from China and was an important social centre where gossip was shared and news from home exchanged.

New arrivals in Auckland would stay in rooms above Wah Lee's until they found other lodgings and work. About 1914, the Chinese Masonic Lodge, the "Chee Kung Tong," was established in the rooms above the shop next to Wah Lee's. Soon, other Chinese rented buildings and before long Grey Street had Chinese boarding houses, opium dens, fan tan, pakapoo and gambling houses. ${ }^{32}$

Ng's paper is not referenced and thus it is unclear whether she is relying on research, memory or hearsay, but something of Greys Avenue's Chinatown is detailed in Wise's Post

${ }^{31}$ Cusins-Lewer \& Gatley "The "Myers Park Experiment" in Auckland, New Zealand, 1913-1916" pp 82-103.

${ }^{32} \mathrm{Ng}$ "Greys Avenue and the Auckland Chinese Scene 1890s-1960s" pp 3-4. 
Office directories from the latter 1930s: Wah Lee, grocer, at no. 45; Luck Hon You, café, at no. 49; Chinese Masonic Society (originally a political group), also at no. 49; Hoi Jung café, at no. 59 - all located at the bottom of Greys Avenue, where it used to intersect with Cook Street, on the west side. At the top of Greys Avenue, on the east side (no. 130), was Ming Sung, lndr (launderer). The street directories include one Indian name - Naratom Daji, frtr (fruiterer) - at the bottom end near Chinatown (no. 85); and one Māori name - Hataraka M. Poihipi, intrprtr (interpreter) - who was resident in Grey Terrace, which used to be a loop road off the west side of Greys Avenue, but no longer exists.

With its Chinatown, shops and cafés, welfare organisations and churches, crèche, kindergarten and park, it is easy today to imagine Greys Avenue as a lively and engaged urban community. But in the 1930s and 40s, Chinese and Oriental "others" remained stereotyped and feared by many white New Zealanders, particularly when congregated in places like Greys Avenue and Haining Street. ${ }^{33}$ Suspicion had developed from at least the 1860s when an increased

${ }^{33}$ Shum "Remembering Chinatown" p 76. number of Chinese men arrived with the intention of working on gold fields or in related industries. A series of measures - polltaxes; dictation tests; thumb-printing - all served to deter Chinese immigration in the latter nineteenth and early twentieth centuries. $^{34}$ Pressure from the British government led to the rewriting of $\mathrm{New}$ Zealand's immigration legislation in 1920. The Immigration Restriction Amendment Act repealed most of the specific humiliations of Chinese (other than the poll-tax which was not abolished until 1944), but while being acceptable to the British government, it was still intended to keep New Zealand white. ${ }^{35}$

Given the entrenched racism, it is perhaps not surprising that Greys Avenue's reputation as a slum persisted. Eva Wong Ng continues:

Auckland's Chinatown population expanded. There were now three or four stores, restaurants, boarding houses - some of which were used as gambling or opium dens....

The gambling and opium dens were often raided by police. Again, Greys Avenue earned a reputation as an

${ }^{34}$ See O'Connor "Keeping New Zealand White, 1908$1920 "$ p 45.

${ }^{35}$ Moloughney \& Stenhouse "'Drug-besotten, Sinbegotten Fiends of Filth"'" p 44. unsavoury area. The old buildings had deteriorated further, and according to Europeans who remember Greys Avenue in those days, it was a scary, dark, and mysterious place and one to be avoided. ${ }^{36}$

Even though street directories record the names of the Chinese businesses in Greys Avenue, they do not record the names of any Chinese residents. The residents have predominantly British/European names, such as Edgr Halford, drvr; Jack Stewart, cyc dir; Arch. L Ross, engr, etc. Noticeable too is the high proportion of women listed, with no occupations identified, suggesting that they were widows: Mrs Jssie E Richardson; Mrs B Peters; Mrs Susn Griffiths; Mrs Smyth; Mrs C Millar, libr, etc. ${ }^{37}$ But given Shum's suggestion that street directories did not record the names of Chinese occupants, it remains possible that the directories mask their occupancy of houses in Greys Avenue. ${ }^{38}$

Certainly the street directories support Eva Wong Ng's assertions about there being a number of apartments and boarding houses in the street. The term apartment was used to refer to any house where two or more

\footnotetext{
${ }^{36} \mathrm{Ng}$ "Greys Avenue and the Auckland Chinese Scene" p 4.

37 Wise"s Post Office Directory, Auckland 1936, 1940.

${ }^{38}$ Shum "Remembering Chinatown" pp 75,92.
} 
individuals or families were living independently of each other. Thus for Greys Avenue we see: Mrs BM Hume, apts; Mrs Isab Fielder, bdghse; Ms C Schischka, apts; Mrs Dora Penny, apts; R Wynne, apts; Mrs Srh, bdghse; Mrs V Green, apts ${ }^{39}$ - predominantly, but not solely, widows taking in boarders to make ends meet.

Like old photographs of the Grey Street Gully houses prior to their clearance, those taken in Grey Street/Greys Avenue in the 1920s, 30s and 40 s show predominantly timber houses, many two storeyed, looking in need of maintenance, repair and painting, with vegetation that was both overgrown and unkempt. But the word "slum" exaggerates the conditions. Indeed, in 1934 Council officers acknowledged that the Greys Avenue houses were not slums "in the true sense of the word," and could be "more correctly described as "decadent areas"."40 The words "shabby" and "shambling" were also used:

it is the rightful claim which a city of the status of Auckland has on its ratepayers to improve to the fullest

\footnotetext{
39 Wise"s Post Office Directory, Auckland, 1936, 1940.

${ }^{40}$ Memo from City Engineer"s Office to Town Clerk,

Auckland City Council, 28 July 1934. ACC Box 91, File
} 34/226 Part 1. extent possible, the appearance of the shabby, shambling areas which are not only decadent but a blot on Auckland's reputation for progressiveness, and a positive disgrace to the community as a whole." 41

But "decadent," "shabby," and "shambling" are not the same as "slum." And as Eva Wong Ng acknowledges, there was much more to life in Greys Avenue than the stereotypes suggest:

However, those who grew up there tell a different story [i.e. different from the reputation of the place]. As children they had wonderful childhoods. Sure, there were dangers to be considered, for this was the time of the six o'clock pub closing and after 1942 there were many American and New Zealand servicemen around. But with the company of other Chinese children and Myers Park nearby, they made their own fun. ${ }^{42}$

An Auckland City Council map illustrating the findings of the 1935 housing survey of Greys Avenue adds another layer of information to that gleaned from the street directories and old photographs. The map is particularly valuable here because its content is not limited to structural strength and overcrowding. It also identifies "Houses occupied by Asiatics."43

\footnotetext{
${ }^{41}$ Davis "Decadent Areas" p 1.

${ }^{42} \mathrm{Ng}$ "Greys Avenue and the Auckland Chinese Scene" $\mathrm{p}$ 4.

43 "Map of Properties in the Greys Avenue Area Shewing
}

The map shows "Asiatics" at 45-71 Greys Avenue on the west side and 26-34 Greys Avenue on the east, thus stretching slightly beyond the Chinatown revealed by the street directories. The only other buildings identified as "occupied by Asiatics" are at numbers 85-87 Greys Avenue (Naratom Daji's place - the term Asiatic included Indians) and 91-93 Greys Avenue (an address not listed in the street directory and thus one that provides evidence in support of Shum's claim regarding ethnic absences from the street directories).

The address of the Lower Greys Avenue Flats is 95-113 Greys Avenue. Greys Avenue has not been renumbered since that time, but the land now described as nos. 95-113 actually encompasses nos. 95-125. It comes as a surprise that the 1935 housing survey map shows this stretch of Greys Avenue as clear of buildings other than no. 111 and 117, both of which were identified as "structurally unsatisfactory and should be demolished." This map suggests that no. 111, which was occupied by Thos Hare, seamn, and no. 117, by $\mathrm{Mr}$ C Schischka, occupation not listed, ${ }^{44}$

Results of Survey of Housing Conditions" ACC 005/954. ${ }^{44}$ Wise"s Post Office Directory, Auckland, 1936. 
were the only two lots demolished specifically to make way for the Lower Greys Avenue Flats. This is confirmed by a 1945 Herald article. $^{45}$ The other sites had already been cleared, presumably by the Council, before 1935 when the housing survey was conducted. No. 95 Greys Avenue had in fact been a street called Mark Avenue; nos. 95 to 97 had housed a two-storeyed wooden terrace; and nos. 113 and 115 had incorporated six tenancies, two two-storeyed ones at the front of the site and four single-storeyed ones behind - the very conditions that inspired slum rhetoric in this period.

In 1935, the part of Greys Avenue with the most buildings identified for demolition was Chinatown, at the northern end. But it could not be acquired for slum clearance and replacement with state housing because "it [was] zoned in the light commercial area and is not adaptable to or suitable for the purposes of the Housing Department."46 These buildings were acquired and cleared later, to make way for the Auckland City Council's own Civic Building (1954-66) and the open

${ }^{45}$ Indeed these two houses were not cleared until 1945, in conjunction with the start being made on the

construction of the new building. See "Fifty Flats" n.p.

${ }^{46}$ Davis "Decadent Areas" p 4. space in front of it. The parts of Greys Avenue with the second highest number and density of buildings that were structurally unsatisfactory and/or identified for demolition were: (i) those higher up Greys Avenue - nos. 127 to 147 and the Grey Terrace loop road which were replaced by the Upper Greys Avenue Flats in the mid-to-late 1950s; and (ii) those opposite the Upper Greys Avenue site, where the Duxton Hotel and DDB Building now stand. In addition, the Council proposal mentioned at the beginning of this paper, for two blocks of apartments (125 flats), one on either side of Greys Avenue, was also for these two sites, ${ }^{47}$ not for that where the Lower Greys Avenue Flats were built.

As for the houses that were the subject of discussion, I have found no evidence that they were anything other than ageing and in need of maintenance and repair. The houses were tenanted rather than occupied by owners. The occupants were workers and widows, in some cases taking in boarders to make ends meet. The proximity of the Greys Avenue houses to Auckland's Chinatown suggests that some of the boarders may have been Chinese. It seems

${ }^{47}$ City Engineer"s Department to Town Clerk, "Housing" 23 August 1935. See also "Housing Scheme." likely that had these houses not been demolished, they would have been gentrified in the way that many other older houses close to city centres have been. But the slum language motivated people to act. It provided council and government with the ammunition needed to demolish run-down areas of the city and to replace them with new and up-todate accommodation. I am left to ponder the degree of importance that should be attached to the proximity of Greys Avenue to the Auckland Town Hall and Auckland's future civic centre. Further research on the Chinatown/Civic Building site would be useful in clarifying this. 


\section{REFERENCES}

"Auckland Achievement: Block of 50 State Flats as First Step in Slum Clearance" Building Progress (1 November 1947) p 7.

Auckland City Archives Box 91, File 34/226 Part 1.

Bush, G. W. A. Decently and In Order: The Government of the City of Auckland 1840-1971: The Centennial History of the Auckland City Council Auckland: Auckland City Council, 1971.

C.F.B. "Some thoughts on Planning for New Zealand's contribution to the New World Order," unpublished report dated 10 December 1940. ACC 275, Box 231, Item 38/392, Auckland City Archives.

City Engineer's Department to Town Clerk, "Housing" 23 August 1935, Auckland City Archives.

"City Schemes; Housing and Works" New Zealand Herald (12 March 1936). ACC Box 91, File 34/226 Part 1, Auckland City Archives.

CT 478/190, Auckland [Certificate of Title].

Cusins-Lewer, Anéne and Julia Gatley "The "Myers Park Experiment" in Auckland, New Zealand, 1913-1916" Designing Modern Childhoods: History, Space, and the Material Culture of Children Marta Gutman and Ning de Connick-Smith (eds) New Brunswick, N.J.: Rutgers University Press, 2008:82-103.

Cusins-Lewer, Anéne and Julia Gatley "The "Myers Park Experiment" (1913-1916) and Its Legacy in Auckland" Fabrications: The Journal of the Society of Architectural Historians, Australia and New Zealand (June 2002) 12(1):59-80.

Davis, Ernest "Decadent Areas," Confidential Report to Council, 19 December 1940, p. 1. ACC 275, Box 231, Item 38/392, Auckland City Archives, Auckland.

Dock St Mission and Old Folk's Fellowship, The Slums of Auckland: Our Shame and Our Duty; An Appeal to the Public, Auckland: s.p., ca. 1937.

"Fifty Flats: Government Block; Grey's Avenue Scheme [unidentified newspaper, presumably the New Zealand Herald]" (20 June 1945).

"Former Mayoress [unreferenced newspaper article]" Copy in "New Zealand Biographies" 1 (1956): 123. Compiled by and held at Alexander Turnbull Library, Wellington.

Gatley, Julia "Labour Takes Command: A History and Analysis of State Rental Flats in New Zealand 1935-49," MArch thesis, Victoria University of Wellington, 1997.

"Housing Plans: the City Scheme: Move to Defer Work: Operations by Government: Further Consideration"New Zealand Herald (3 November 1936). ACC Box 91, File 34/226 Part 1, Auckland City Archives.

"Housing Scheme: City Council's Plans; Dwellings for Workers; Defence by Deputy Mayor" New Zealand Herald (30 September 1935). ACC Box 91, File 34/226 Part 1, Auckland City Archives.

"Map of Properties in the Greys Avenue Area Shewing Results of Survey of Housing Conditions" ACC 005/954, Auckland City Archives.

Mayne, Alan The Imagined Slum: Newspaper Representation in Three Cities, 1870-1914 Leicester, London and New York: Leicester University Press, 1993.

Memo from City Engineer's Office to Town Clerk, Auckland City Council, 28 July 1934. ACC Box 91, File 34/226 Part 1, Auckland City Archives.

Moloughney, Brian and John Stenhouse "''Drug-besotten, Sin-begotten Fiends of Filth": New Zealanders and Oriental Others" New Zealand Journal of History (1999) 33(1):43-64.

"The Myers Park" New Zealand Herald (28 January 1915):6.

"New Park: Gift of Mr Myers, MP" New Zealand Herald (30 September 1913):8.

Ng, Eva Wong "Greys Avenue and the Auckland Chinese Scene 1890s- 
1960s" Crouching Tiger, Hidden Banana Conference AUT University, Auckland, 4 June 2005, 5pp.

O'Connor, P. S. "Keeping New Zealand White, 1908-1920" New Zealand Journal of History (April 1968) 2(1):41-65.

Parr, C. J. "Parks, Playgrounds, and Open Spaces as Places of Recreation, of Physical Development, and of Rest" Official Volume of Proceedings of the First New Zealand Town-planning Conference and Exhibition, Wellington ... 1919 Wellington: Government Printer, 1919:236-242.

Sayers, Alan "Rat-Infested Slums Endanger Health of Aucklanders" Auckland Star (29 August 1946). ACC 219 Box 91 Item 34/226 Part 2.

Schrader, Ben "Avoiding the Mistakes of the "Mother Country:" The New Zealand Garden City Movement, 1900-1926" Planning Perspectives (October 1999) 14(4):395-411.

Shum, Lynette "Remembering Chinatown: Haining Street of Wellington" Unfolding History, Evolving Identity: The Chinese in New Zealand Manying Ip (ed) Auckland: Auckland University Press, 2003:73-93.

"State Flats in City: Symonds Street and Grey's Avenue" New Zealand Herald (8 September 1947):6.

Town Clerk's Series 275 Box 5 File 1913/304, Auckland City Archives, Auckland 